\title{
Effects of associations of tannins from Anacardium occidentale and Anadenanthera colubrina with cephalosporin against bovine Staphylococcus aureus isolates
}

\section{Efeitos da associação de taninos de Anacardium occidentale e Anadenanthera colubrina à cefalosporina sobre Staphylococcus aureus isolados de bovinos}

\author{
Andréia Vieira Pereira', Marcelo Biondaro Góis ${ }^{2 *}$, Tatiane Kelly Barbosa Azevêdo ${ }^{3}$, \\ Fabiana Nabarro Ferraz', Suellen Laís Vicentino Vieira', Vanessa Melo Cavalcanti-Dantas ${ }^{4}$, \\ Jozinete Vieira Pereira ${ }^{5}$, Onaldo Guedes Rodrigues ${ }^{3}$, Maria do Socorro Vieira Pereira ${ }^{4}$
}

\begin{abstract}
The association of natural compounds isolated from medicinal plants with conventional antibiotics, both with similar mechanisms of action, have become a viable alternative strategy to overcome the problem of drug resistance. This study aimed to evaluate the in vitro antimicrobial activity of tannic substances present in the bark of Anacardium occidentale and Anadenanthera colubrina against samples of Staphylococcus aureus when in combination with cephalexin. These combinations were evaluated by determining the minimum inhibitory concentration (MIC). For this purpose, tannins and cephalexin were serially dissolved in distilled water at concentrations ranging from $0.976 \mathrm{mg} / \mathrm{mL}$ to $500 \mathrm{mg} / \mathrm{mL}$ and $2 \mathrm{mg} / \mathrm{mL}$ to $512 \mathrm{mg} / \mathrm{mL}$, respectively. When combined, the compounds inhibited $S$. aureus growth forming halos ranging from 0.9 to $46 \mathrm{~mm}$ with an MIC of $7.8 \mathrm{mg} / \mathrm{mL}$ (tannins) and $4 \mu \mathrm{g} / \mathrm{mL}$ (cephalexin). The resulting effect of the combination of natural and synthetic substances with similar mechanisms of action presented better results than when tested alone. Thus, the conclusion is that both the tannins and cephalexin had their antimicrobial action enhanced when used in combination, enabling the use of lower concentrations while maintaining their antibacterial effect against strains of $S$. aureus.
\end{abstract}

KEYWORDS: tannins; natural products; antibiotics; microorganisms.
RESUMO: A associação de compostos naturais, isolados de plantas medicinais, com antibióticos convencionais, com mecanismos de ação semelhantes, torna-se uma estratégia alternativa e viável para superar o problema da resistência. Assim, nosso objetivo foi avaliar a atividade antimicrobiana in vitro de substâncias tânicas presentes na casca de Anacardium occidentale e Anadenanthera colubrina associadas à cefalexina, sobre amostras de Staphylococcus aureus. Avaliamos essa associação por meio da determinação da concentração mínima inibitória. Dessa forma, taninos e a cefalexina foram dissolvidos de forma seriada em água destilada em concentraçóes variando de $0,976 \mathrm{mg} / \mathrm{mL}$ a $500 \mathrm{mg} / \mathrm{mL}$ e $2 \mu \mathrm{g} / \mathrm{mL}$ a $512 \mu \mathrm{g} / \mathrm{mL}$, respectivamente. Quando associados, inibiram o crescimento de $S$. aureus formando halos que variaram de 0,9 a $46 \mathrm{~mm}$ com concentração mínima inibitória de $7,8 \mathrm{mg} / \mathrm{mL}$ (taninos) $/ 4 \mu \mathrm{g} / \mathrm{mL}$ (cefalexina). O efeito resultante da associação de substâncias, natural e sintética, com mecanismos de ação semelhantes, apresentou resultados superiores aos observados quando testados isoladamente. Podemos concluir que os taninos e a cefalexina tiveram sua ação antimicrobiana potencializada quando utilizados em associação, permitindo o uso de uma menor concentração, mantendo seu efeito antibacteriano sobre cepas de $S$. aureus.

PALAVRAS-CHAVE: taninos; produtos naturais; antibióticos; micro-organismo.

\footnotetext{
'Universidade Estadual de Maringá - Maringá (PR), Brazil

¿Universidade Federal da Bahia - Salvador (BA), Brazil

${ }^{3}$ Universidade Federal de Campina Grande - Patos (PB), Brazil

${ }^{4}$ Universidade Federal da Paraíba - João Pessoa (PB), Brazil

${ }^{5}$ Universidade Estadual da Paraíba - Campina Grande (PB), Brazil

*Corresponding author: marcelobiondaro@gmail.com

Received on: 08/02/2016. Accepted on: 04/05/2018
}

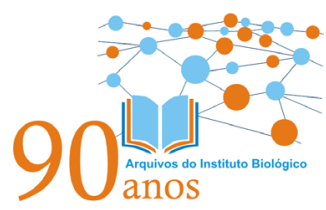




\section{INTRODUCTION}

The emergence of antibiotic resistant Staphylococcus aureus strains occurs due to improper and abusive use of antimicrobial agents, leading to their resistance to drugs in current use. This has become a public health problem (MASURANI; TAVARES, 2007), and the treatment of bacterial infection cases related to this strain is becoming increasingly difficult. This has promoted a growing interest in scientific circles for compounds obtained from medicinal plants, which are effective against microorganisms resistant to conventional medicines. They can minimize side effects and are more affordable. Among the tannins, there is a pool of components, and their synergisms are often preponderant (ALMEIDA et al., 2012; MENEZES et al., 2014; HIGINO et al., 2015; PEREIRA et al., 2015; CAVALCANTI-DANTAS et al., 2016).

Tannins act directly against cellular organelles and within the cell membranes of various microorganisms, inhibiting their growth (MIN et al., 2008; RODRIGUES et al., 2014; AGOSTINI-COSTA et al., 2015). Recent studies indicate that tannins present great potential in binding proteins and adhesins, interfering directly in the substrate availability necessary for bacterial metabolism and growth (JONES et al., 1994; HASLAM, 1996; GUIMARÃES-BEELEN et al., 2006; RODRIGUES et al., 2014).

Among the antibiotics most prescribed to treat infections caused by $S$. aureus, 1 st generation cephalosporin (Cephalexin) presents action against many bacteria including: S. aureus, Staphylococcus epidermides, Streptococcu spneumoniae, Streptococcus pyogenes, Eschericha coli, Haemophilus influenzae, Proteus mirabilis, Klebsiella pneumoniae and Moraxella catarrhalis (PRESCOTT et al., 2002; RODRIGUES; BERTOLDI, 2010; SAEKI et al., 2011), and constitutes a first option for skin infections, in which Staphylococcus aureus is the most probable causative agent (WHITE, 1996; PRESCOTT et al., 2002). Considering the increasing prevalence of multidrug-resistant $S$. aureus, which causes many diseases in humans and in animals (FREITAS et al., 2005; RUEGG, 2007), the use of tannins, associated with conventional antibiotics, can reduce morbidities and combat disease. In this context, tannins isolated from Anadenanthera colubrina (Vell) Brenan (Red Angico), and Anacardium occidentale Linn. (Cashew) may be good therapeutic candidates. They can be used alone (MENEZES et al., 2014; GONÇALVES et al., 2015; HIGINO et al., 2015; PEREIRA et al., 2015), or as mentioned above, in association with antibiotics. However, studies focusing on their solitary (or associated) biological activities have not been found in the literature. This study aimed to evaluate the in vitro antimicrobial activity of tannin substances present in the bark of $A$. occidentale and $A$. colubrina when associated with cephalexin against multidrug-resistant $S$. aureus samples of bovine origin.

\section{MATERIAL AND METHODS}

\section{Anadenanthera colubrina (Vell) Brenan and Anacardium occidentale L.}

Stem husks of "Red Angico" (A. colubrina) and "Cashew" (A. occidentale) were collected and prepared in NUPEÁRIDO, the Semi-arid Research Nucleus of Universidade Federal de Campina Grande (UFCG). The plants were collected (four samples), and deposited at the Prof. Lauro Pires Xavier Herbarium and the Pharmaceutical Technology Laboratory reference collection, both at Universidade Federal da Paraíba (UFPB). The identification of the samples was carried out in the Virtual Herbarium of Flora and Fungi (INCT) registered with the code CEN 50716 and CEN 6191 respectively.

\section{Extraction of tannin substances for antimicrobial activity evaluation}

The husks were packed in plastic bags so as to not lose moisture. In the laboratory, two samples were used; they were cut into smaller fragments, homogenized, weighed and dried in an oven at $103 \pm 2^{\circ} \mathrm{C}$ for $48 \mathrm{~h}$ for determination of moisture content (dry basis). The husks were then air dried and milled in a forage harvester. The material was classified, and what passed through a $2 \times 2 \mathrm{~cm}$ mesh sieve was used. After this process, four samples were collected; two of these were ground in a Willey-type mill to obtain smaller and more homogeneous particle sizes aimed to quantify the tannins present in $A$. colubrina and $A$. occidentale in accordance with PAES et al. (2006). The extraction of tannins was performed in water, using a rotary digester, at a temperature of $70 \pm 5^{\circ} \mathrm{C}$ for $2 \mathrm{~h}$. For each $2 \mathrm{~kg}$ of husks, $10 \mathrm{~L}$ of water were respectively added (1:5). Each sample was submitted to two extractions (GUANGCHENG et al., 1991). The solution obtained was homogenized, strained, and placed in aluminum trays, and then placed in an oven with forced ventilation and kept at $70 \pm 3^{\circ} \mathrm{C}$ until complete moisture evaporation. The dry material, final product of the evaporation process, was crushed in a household multiprocessor and sifted in a 60 mesh sieve; corresponding to pure tannin.

\section{Acquisition of Staphylococcus aureus strains}

Collection of milk samples and nasal swabs were performed in NUPEÁRIDO, the Semi-arid Research Nucleus of Universidade Federal de Campina Grande (UFCG), in the municipality of Patos, State of Paraíba, Brazil.

Samples were obtained from 30 naturally infected lactating cattle. After washing the udders with soap and water, 
drying with a paper towel, and disinfecting the ostium of the udders with ethyl alcohol at $70^{\circ} \mathrm{GL}$, approximately $5 \mathrm{~mL}$ of milk was collected from each mammary quarter for the California Mastitis Test reagent (CMT), aseptically, with an inclined pipe positioned horizontally.

The nasal swab was collected, and all samples were stored in sterile threaded pipes; identified and shipped under refrigeration in boxes made of insulated material. All materials were sent for processing, microbiological examination and S. aureus identification in the Genetics and Microbiology Laboratory of UFPB/CCEN.

In order to identify multidrug-resistant strains, the sensitivity to antibiotics was previously evaluated in three different categories using disk diffusion tests in Petri plates containing Muller Hinton agar (MHA), in accordance with YOUN et al. (2011). In this study, 11 strains of $S$. aureus were chosen: one strain of $S$. aureus (ATCC 25925) and ten of strains of S. aureus from bovine origin obtained from the udders $(104 \mathrm{U}$, $120 \mathrm{U}, 125 \mathrm{U}, 787 \mathrm{U}, 250 \mathrm{U}, 275 \mathrm{U}, 282 \mathrm{U}, 301 \mathrm{U}, 305 \mathrm{U}$ and $335 \mathrm{U}$ ). The strains were tested against $\beta$-lactams (ampicillin and penicillin), as well as aminoglycosides (neomycin, streptomycin, and tetracycline).

\section{Antimicrobial activity}

Tannins were dissolved in sterile distilled water and filtered in a $0.22 \mu \mathrm{m}$ membrane filter $\left(\mathrm{TPP}^{\circledR}\right)$ at $25 \mathrm{mg}$ of tannin for each $\mathrm{mL}$ of distilled water. The initial solution was diluted serially, obtaining concentrations ranging from $500 \mathrm{mg} / \mathrm{mL}$ to $0.976 \mathrm{mg} / \mathrm{mL}$; these were added individually to the S. aureus bacterial cultures.

The bacteria were previously grown in BHI medium (Brain Hearth Infusion, Sigma ${ }^{\mathrm{TM}}$ ) at $37^{\circ} \mathrm{C}$ for $24 \mathrm{~h}$, and the suspensions were adjusted to the Nephelometric 0.5 McFarland standard scale turbidity standard. This corresponded to approximately $1.5 \times 10^{8}$ colony-forming units $(\mathrm{CFU}) / \mathrm{mL}$, which were diluted in BHI broth for a concentration of $1.5 \times 10^{5} \mathrm{CFU} / \mathrm{mL}$.

Aliquots of $50 \mu \mathrm{L}$ were removed from these tubes and disseminated in Petri plates containing Muller Hinton agar (MHA). Holes were made in the culture mediums with a $6 \mathrm{~mm}$ diameter glass tube and filled with $25 \mu \mathrm{L}$ of tannin and cephalexin diluted in distilled water. The initial concentration of tannin for serial dilution was $500 \mathrm{mg} / \mathrm{mL}$, and cephalexin at $512 \mu \mathrm{g} / \mathrm{mL}$. This concentration was selected in accordance with the results obtained by SULEIMAN et al. (2013). The plates were kept in the oven at $37^{\circ} \mathrm{C}$ for $24 \mathrm{~h}$. Minimum inhibitory concentration (MIC) was considered as the lowest concentration of antibiotic that completely inhibited bacterial growth (CLSI, 2010) for the diameter of the bacterial growth inhibition halos (BARRY, 1991; JORGENSEN et al., 1999) formed around each hole. The halos were measured and the results displayed in millimeters $(\mathrm{mm})$.
A qualitative method was used, which allowed classifying the bacterial samples as susceptible or resistant to the association used (CLSI, 2010). Strains were considered sensitive when presenting halos greater than $10 \mathrm{~mm}$, according to the preliminary studies (PEREIRA et al., 2015; MENEZES et al., 2014; CAVALCANTI-DANTAS et al., 2016).

\section{STATISTICAL ANALYSIS}

Sensitivity testing was carried out in triplicate and evaluated using analysis of variance by the Kruskal-Wallis test, followed by Dunn's test, comparing tendencies of bacterial growth inhibition (CALEGARI-JACQUES, 2003). Tests were considered significant when the $\mathrm{p}$-value was less than $5 \%$. The data were also recorded in the form of a database in the computer program SPSS (Statistical Package for Social Sciences) for Window $^{\circledR}$, version 15.0; and analyzed by means of descriptive and inferential statistics.

\section{RESULTS}

Initially, the resistance profiles of $S$. aureus strains against $\beta$-lactams (ampicillin and penicillin) and aminoglycosides (neomycin, streptomycin, and tetracycline) in this way were verified and considered as $S$. aureus strains susceptible or resistant to the association used, thus corroborating analyses conducted by BARRETO et al. (2014). The protocol used in this study allowed the determination of the antimicrobial activity (MIC) of stem bark tannins from $A$. occidentale and A. colubrina when associated with cephalosporin (Cephalexin) against multidrug-resistant $S$. aureus samples of bovine origin.

The inhibition halos for A. occidentale and A. colubrina associations together with cephalexin had diameters ranging from 0.9 to $46 \mathrm{~mm}$ at all dilutions, thus presenting 100\% effectiveness at the 1:64 dilution (Table 1). Inhibition of growth occurred homogeneously and according to the concentration of the tannic substance in associations with cephalexin.

It was observed that the associations in the higher concentrations of both tannins $(\mathrm{mg} / \mathrm{mL})$ and cephalexin $(\mu \mathrm{g} / \mathrm{mL})$ the diameter of the growth inhibitory halos of $S$. aureus greater varying between $(43.45 \pm 2.25)$; $(38.27 \pm 1.79)$; $(33.82 \pm 2.16)$ and $(25.91 \pm 2.16)$ respectively, without differing between them $(\mathrm{p}=0.1000)$. The associations at lower concentrations of both tannins $(\mathrm{mg} / \mathrm{mL})$ and cephalexin $(\mu \mathrm{g} / \mathrm{mL})$ showed the diameter of the smaller growth inhibitory halos of $S$. aureus varying between $(21.09 \pm 1.57),(12 \pm 1)$ and $(9.9 \pm 0.94)$ respectively, but not differing from each other, differing from the halos values 
of the highest concentrations $(\mathrm{p}<0.05)$. This last concentration $(7.8 \mathrm{mg} / \mathrm{mL}+8 \mu \mathrm{g} / \mathrm{mL}$ ) was considered the MIC (Tables 1 and 2$)$. It is noteworthy that at this last concentration (7.8/8); four strains showed resistance to the Cephalexin - A. occidentale association; corresponding to $36.3 \%$ of samples (halos less than $9 \mathrm{~mm}$; Table 1).

Another six strains tested showed resistance to the Cephalexin - A. colubrina association; corresponding to
$54.5 \%$ of the samples (halos with less than $9 \mathrm{~mm}$; Table 2). In view of the inhibition halos when Cephalexin and the tannins were used separately, the $A$. occidentale tannin showed an MIC of $62.5 \mathrm{mg} / \mathrm{mL}$, with halos of $11 \mathrm{~mm}$, the $A$. colubrina tannin obtained an MIC of $31.25 \mathrm{mg} / \mathrm{mL}$, with halos that ranged from 10 to $13 \mathrm{~mm}$, and Cephalexin obtained an MIC of $32 \mu \mathrm{g} / \mathrm{mL}$ with halo dimensions that ranged from 29 to $33 \mathrm{~mm}$.

Table 1. Mean \pm standard deviation of the minimum inhibitory concentration (MIC); with diameters of inhibition halos in millimeters (mm), on solid medium; association of cephalexin with Anacardium occidentale tannin; against Staphylococcus aureus.

\begin{tabular}{|c|c|c|c|c|c|c|c|}
\hline Dilutions & $1: 1$ & $1: 2$ & $1: 4$ & $1: 8$ & $1: 16$ & $1: 32$ & $1: 64^{*}$ \\
\hline \multicolumn{8}{|c|}{ Concentration in $\mathrm{mg} / \mathrm{mL}+\mu \mathrm{g} / \mathrm{mL}$} \\
\hline S. aureus & $500+512$ & $250+256$ & $125+128$ & $62.5+64$ & $31.2+32$ & $15.6+16$ & $7.8+8$ \\
\hline $104 \mathrm{U}$ & 42 & 35 & 30 & 25 & 20 & 13 & 10 \\
\hline $120 \mathrm{U}$ & 46 & 37 & 32 & 27 & 21 & 12 & 09 \\
\hline $125 \mathrm{U}$ & 44 & 39 & 35 & 29 & 24 & 12 & 10 \\
\hline $156 U$ & 42 & 38 & 36 & 28 & 23 & 14 & 12 \\
\hline $250 \mathrm{U}$ & 45 & 40 & 37 & 29 & 23 & 11 & 09 \\
\hline $275 U$ & 43 & 38 & 33 & 25 & 20 & 10 & 09 \\
\hline $282 \mathrm{U}$ & 40 & 38 & 34 & 26 & 21 & 13 & 10 \\
\hline $301 \mathrm{U}$ & 46 & 38 & 34 & 25 & 21 & 11 & 09 \\
\hline $305 \mathrm{U}$ & 40 & 37 & 35 & 22 & 20 & 12 & 10 \\
\hline $335 \mathrm{U}$ & 44 & 39 & 36 & 25 & 20 & 12 & 10 \\
\hline ATCC & 46 & 42 & 30 & 24 & 19 & 12 & 11 \\
\hline $\mathrm{M} \pm \mathrm{SD}$ & $43.45 \pm 2.25^{a}$ & $38.27 \pm 1.79^{a c}$ & $33.82 \pm 2.16^{a c}$ & $25.91 \pm 2.16^{a}$ & $21.09 \pm 1.57^{\mathrm{bd}}$ & $12 \pm 1^{\text {bd }}$ & $9.9 \pm 0.94^{b c}$ \\
\hline
\end{tabular}

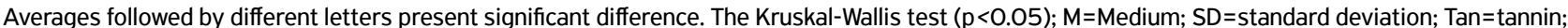
$\mathrm{U}=$ Udder; Cef=Cephalexin; ${ }^{*} \mathrm{MIC}=$ Minimum Inhibitory Concentration at a dilution of $1: 64=7.8 \mathrm{mg} / \mathrm{mL}$ of tannin and $8 \mu \mathrm{g} / \mathrm{mL}$ of cephalexin.

Table 2. Mean \pm standard deviation of the minimum inhibitory concentration (MIC); with diameters of inhibition halos in millimeters (mm), on solid medium; association of Cephalexin with Anadenanthera colubrina extract against Staphylococcus aureus.

\begin{tabular}{|c|c|c|c|c|c|c|c|}
\hline Dilutions & $1: 1$ & $1: 2$ & $1: 4$ & $1: 8$ & $1: 16$ & $1: 32$ & $1: 64^{*}$ \\
\hline \multicolumn{8}{|c|}{ Concentration in $\mathrm{mg} / \mathrm{mL}+\mu \mathrm{g} / \mathrm{mL}$} \\
\hline S. aureus & $500+512$ & $250+256$ & $125+128$ & $62.5+64$ & $31.2+32$ & $15.6+16$ & $7.8+8$ \\
\hline $104 \mathrm{U}$ & 40 & 38 & 35 & 29 & 25 & 13 & $\mathrm{OO}$ \\
\hline $120 \mathrm{U}$ & 39 & 36 & 32 & 30 & 26 & 15 & 13 \\
\hline $125 \mathrm{U}$ & 35 & 33 & 30 & 26 & 21 & 12 & 09 \\
\hline $156 U$ & 37 & 32 & 29 & 22 & 19 & 14 & 10 \\
\hline $250 \mathrm{U}$ & 39 & 36 & 34 & 27 & 22 & 11 & $\mathrm{OO}$ \\
\hline $275 U$ & 38 & 35 & 29 & 25 & 23 & 14 & 10 \\
\hline $282 \mathrm{U}$ & 40 & 37 & 34 & 28 & 23 & 13 & $\mathrm{OO}$ \\
\hline $301 \mathrm{U}$ & 38 & 36 & 29 & 25 & 22 & 13 & $\mathrm{OO}$ \\
\hline $305 \mathrm{U}$ & 38 & 35 & 29 & 24 & 21 & 14 & 10 \\
\hline $335 \mathrm{U}$ & 39 & 36 & 34 & 30 & 26 & 16 & 12 \\
\hline ATCC & 37 & 35 & 32 & 28 & 25 & 12 & $\mathrm{OO}$ \\
\hline $\mathrm{M} \pm \mathrm{SD}$ & $38.8 \pm 1.47^{a}$ & $35.36 \pm 1.69^{a c}$ & $31.55 \pm 2.42^{\mathrm{ac}}$ & $26.73 \pm 2.57^{a}$ & $23 \pm 2.28^{b d}$ & $13.36 \pm 1.43^{\mathrm{bd}}$ & $5.8 \pm 5.67^{\mathrm{bc}}$ \\
\hline
\end{tabular}

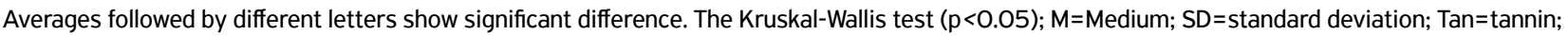
$\mathrm{U}=$ Udder; Cef=Cephalexin; * MIC=Minimum Inhibitory Concentration at a dilution of $1: 64=7.8 \mathrm{mg} / \mathrm{mL}$ of $\mathrm{tannin}$ and $8 \mu \mathrm{g} / \mathrm{mL}$ of cephalexin. 


\section{DISCUSSION}

From the results obtained, it can be observed that the tannins presented significant pharmacological effect. In the in vitro assay, both tannins, when associated with cephalexin, presented potentiated antimicrobial action against multidrug-resistant $S$. aureus.

$S$. aureus presents variability in developing resistance to multiple antimicrobial agents, causing physiological disorders and disease processes in individuals (MONROE; LEWIS, 2000). This variability contributes to its survival and dissemination in hospital environments (MUSUMECI et al., 2003; MAIA et al., 2009).

Currently, there are many limitations for medicines when treating diseases caused by multiresistant microorganisms (ENTENÇA; MOREILLON, 2008). Compounds obtained from medicinal plants present various biological activities against pathogenic Gram-positive and Gram-negative species (ABUBAKAR, 2009; AHMED et al., 2010), which allows their use. Compounds such as tannins can be used either pure or in association with conventional antimicrobial agents, representing a greater strategy to overcome multidrug-resistant S. aureus, among others.

In the present study, the samples studied were sensitive to low concentrations of tannins when associated with cephalexin. According to LOGUERCIO et al. (2005). The antimicrobial activity of tannins occurs through interaction between tannin and the bacterial cell wall. SCALBERT (1991) states that this interaction interferes directly in transport as well, the availability of essential ions and nutrients to maintain the microbial metabolism. MENEZES et al. (2014) and PEREIRA et al. (2015) investigated the antimicrobial activity of tannins isolated from the stem bark of A. luxembourg against dental biofilm formations of $S$. aureus, S. mutans, S. mitis, S. sanguis, Streptococcus oralis, Streptococcus salivarius, and Lactobacillus casei, which all showed promise with MICs that ranged from $0.062 \mathrm{mg} / \mathrm{mL}$ to $31.25 \mu \mathrm{g} / \mathrm{mL}$ (MENEZES et al., 2014; PEREIRA et al., 2015). Tannins of other native species from Brazil's caatinga biome (exclusively) were tested against $S$. aureus, Escherichia coli, Pseudomonas aeruginosa, and Bacillus subtilis, and presented excellent antimicrobial activities (GONÇALVES et al., 2015; HIGINO et al., 2015; PEREIRA et al., 2015). PEREIRA et al. (2015) evaluated the activity of tannin isolated from the bark of Mimosa tenuiflora and demonstrated an MIC of $31.2 \mu \mathrm{g} / \mathrm{mL}$ against $S$. aureus. The antimicrobial activity of tannins isolated from the bark of Dalbergia stipulacea was verified by PEREIRA et al. (2015) against strains of $S$. aureus of animal origin, and obtaining an MIC of $62.5 \mu \mathrm{g} / \mathrm{mL}$. More recent data regarding the antimicrobial activity of condensed $P$. stipulacea tannin was observed by CAVALCANTI-DANTAS et al. (2016), having found an MIC of $31.25 \mathrm{mg} / \mathrm{mL}$ against strains of $S$. aureus. In the present study, the methodology was based on studies by these authors.
The antimicrobial activity of the tannins obtained from the bark of Mimosa arenosa was observed in both Gram-positive and Gram-negative bacteria such as: $S$. aureus, E. coli, P. aeruginosa, and B. subtilis with MICs ranging from 250 to $1000 \mu \mathrm{g} / \mathrm{mL}$ (GONÇALVES et al., 2015). The authors observed that the antibacterial activity exerted by tannins from $M$. arenosa was bacteriostatic against all strains tested.

The results in this study demonstrated synergism between cephalexin and the tested tannins against multidrug-resistant $S$. aureus samples. The tannins of $A$. occidentale and A. colubrina presented respective MICs of $62.5 \mathrm{mg} / \mathrm{mL}$ and $31.2 \mathrm{mg} / \mathrm{mL}$ when used pure. Cephalexin, when used alone, presented an MIC of $32 \mu \mathrm{g} / \mathrm{mL}$. The associations of tannins with the antibiotic were more expressive. We saw antimicrobial action even at dilutions of 1:64 considering the MICs for tannin contents at $7.8 \mathrm{mg} / \mathrm{mL}$, and at $8 \mu \mathrm{g} / \mathrm{mL}$ for Cephalexin. This demonstrates that the effect of the antibiotic was potentiated by the tannin addition, which, even in low concentrations, promoted better antimicrobial action. This likely occurred due to their interactions, and to synergism in their mechanisms of action.

Cephalexin interrupts the synthesis of peptidoglycan and inhibits the action of the enzyme involved in cell membrane trans-peptidation, preventing connections between tetra-peptide chains of peptidoglycan, and promoting lysis of bacterium cell wall (SPINOSA, 2011). Tannins are oligomers and polymers formed by poly-condensation of two or more flavanols and flavandiol, which in turn act similarly by forming tannin-protein complexes and/or polysaccharides at the bacterial cell membrane. The formation of these complexes leads to protein solubility reductions, promoting aggregation and precipitation of proteins present in the membrane, and inhibiting the action of microbial enzymes, thus depriving the organism of substrates essential to growth. This causes lysis of the plasma membrane (GUIMARÃES-BEELEN et al., 2006; RODRIGUES et al., 2014; CAVALCANTI-DANTAS et al., 2016). In accordance with SPINOSA (2011), substances that act against the plasma membrane of the bacterial cell present mechanisms of action that promote modification of its structure, and interfere in the transport systems of nutrients, ions, and other molecules. Synergism of these two substances promotes an increase of physiological response (SPINOSA, 2011; RANG et al., 2012), and may be responsible for the results obtained in the present study.

In the present study, a potentiating effect was observed in the association of two substances obtained from medicinal plants and a conventional medicine. Both present a similar mechanism of action. The results demonstrated that the combined action between them was significantly greater than the sum of the effects achieved by each one alone. Through this association, it can be observed that the tannins present a significant pharmacological effect when associated with cephalexin, and that both the tannins and cephalexin had their 
in vitro antimicrobial action maximized against the tested multiresistant microorganisms. In vivo studies need to be performed to test dosage safety and to reduce the overuse of the antibiotic, in order to maintain its antibacterial effect against multidrug-resistant $S$. aureus strains. According to SAR et al. (2012), the main advantage in using associated antibiotics that have the same mechanism of action is that the association allows potentiation of their effects, with consequent reductions in the drug dose, while maintaining therapeutic efficacy and promoting its effects.

Currently, there is a growing number of publications concerning the use of medicinal plants and their metabolites in in vitro experimental models against multidrug-resistant $S$. aureus (MANSOURI, 1999; HEYMAN et al., 2009; MENEZES et al., 2014; PEREIRA et al., 2015; CAVALCANTI-DANTAS et al., 2016). However, more systematized information is needed concerning possible clinical and pathological aspects resulting from such associations of conventional medicines with tannins.

\section{CONCLUSION}

When used in association, the tannins and cephalexin presented augmented antimicrobial action. The results of this study suggest that the antibacterial activity demonstrated against multiresistant strains of $S$. aureus was achieved due to a potentiating effect introduced by the tannins. Thus, tannins may be used in association with cephalexin against diseases caused by multidrug-resistant $S$. aureus. These findings, in favor of such economically viable compounds, add to an important list of new alternatives to help in infection control.

| | | | | | | | | | | | | | | | | | | | | | | | | | | | | | | | | | | | | | | | | | | | | | | | | | | | | | | | | | | | | | | | | | | | | | | | | | | | | | | | | | | | | | | | | | | | | | | | | | | | | | | | | | | | | | | | | | | | | | | | | | | | | | | | | | | | | | | | | | | | | | | | | | | | | | | | | | | | | | | | | | | | | | | | | | | | | | | | | | | | | | | | | | | | | | | | | | | | | | | | | | | | | | | | | REFERENCES

ABUBAKAR, M.E. Efficacy of crude extracts of garlic (Allium sativum Linn.) against nosocomial Escherichia coli, Staphylococcus aureus, Streptococcus pneumoniea and Pseudomonas aeruginosa. Journal of Medicinal Plants Research, Nigeria, v.3, p.179-85, 2009.

AGOSTINI-COSTA, T.S.; TEODORO, A.F.P.; ALVES, R.B.N.; BRAGA, L.R.; RIBEIRO, I.F.; SILVA, J.P.; QUINTANA, L.G.; BURLE, M.L. Total phenolics, flavonoids, tannins and antioxidant activity of Lima Beans conserved in a Brazilian Genebank. Ciência Rural, Santa Maria, v.45, p.335-341, 2015. http://dx.doi. org/10.1590/0103-8478cr20140030

AHMED, Z.; KHAN, S.S.; KHAN, M.; TANVEER, A.; LONE, Z.A. Synergistic Effect of Salvadora persica Extracts, Tetracycline and Penicillin Against Staphylococcus aureus. African Journal of Basic and Applied Sciences, Cairo, v.2, p.25-29, 2010.

ALMEIDA, C.F.C.B.R.; CABRAL, D.L.V.; ALMEIDA, C.C.B.R.; AMORIM E.L.C.; ARAÚJO, J.M.; ALBUQUERQUE, U.P. Comparative study of the antimicrobial activity of native and exotic plants from the Caatinga and Atlantic Forest selected through an ethnobotanical survey. Pharmaceutical Biology, Oxfordshire, v.50, p.201-207, 2012. http://dx.doi.org/10.3109/1388 0209.2011 .596205

BARRETO, H.M.; LIMA, I.S.; COELHO, K.M.R.N.; OSÓRIO, L.R.; MOURÃO, R.A.; SANTOS, B.H.C.; COUTINHO, H.D.M.; ABREU, A.P.L.; MEDEIROS, M.G.F.; LOPES, A.M.G. Effect of Lippia origanoides H.B.K. essential oil in the resistance to aminoglycosides in methicillin resistant Staphylococcus aureus. European Journal of Integrative Medicine, London, v.6, p.560-564, 2014. http:// dx.doi.org/10.1016/j.eujim.2014.03.011
BARRY, A.L. Procedures and theoretical considerations for testing antimicrobial agents in agar media. In: Lorian, Antibiotics in Laboratory Medicine. Baltimore: The Williams \& Wilkins Co., Md., 3 ed. 1991.

CALEGARI-JACQUES, S.M. Bioestatística: princípios e aplicações. Porto Alegre: Artmed, p.264, 2003.

CAVALCANTI-DANTAS, V.M.; MEDEIROS, K.L.; AZEVEDO, T.K.B.; SANTANA, G.M.; PEREIRA, A.V.; GOIS, M.B.; PEREIRA, M.S.V.; PEREIRA, J.V. Taninos: principal componente do extrato Piptadenia stipulacea (Benth) Ducke inibe o crescimento de cepas clínicas de Staphylococcus aureus de origem bovina. Biotemas, Santa Catarina, v.29, p.109-112, 2016. https://doi. org/10.5007/2175-7925.2016v29n1p 109

CLSI - Clinical and Laboratory Standards Institute (CLSI). Performance standards for antimicrobial susceptibility testing, twentieth information supplement. v.32, n.3, Wayne: CLSI, 2010. 264p.

ENTENZA, J.M.; MOREILLON, P. Tigecycline in combination with other antimicrobials: a review of in vitro, animal and case report studies. International Journal of Antimicrobial Agents, Marseille, v.34, p.1-9, 2008. https://doi.org/10.1016/j. ijantimicag.2008.11.006

FREITAS, M.F.L.; PINHEIRO JUNIOR, J.W.; STAMFORD, T.L.M.; REBELO, A.; SILVA, D.R.; SILVEIRA FILHO, V.M.; SANTOS, F.G.B.; DE SENA, M.J.; MOTA, R.A. Perfil de sensibilidade antimicrobiana in vitro de Staphylococcus coagulase positivos isolados de leite de vacas com mastite no agreste do estado de Pernambuco. Arquivos do Instituto Biológico, São Paulo, v.72, p.171-177, 2005. 
GONCALVES, G.F.; VIEIRA, M.S.; PESSOA, H.L.F. Avaliação toxicológica de taninos de Mimosa arenosa (Mimosaceae). Novas Edições Acadêmicas, 2015.

GUANGCHENG, Z.; YUNLU, L.; YAZAKI, Y. Extractive yiels, Stiasny values and polyflavonoid content in barks from six acacia species in Australia. Journal of the Institute of Foresters of Australia, Australia, v.54, p.154-156, 1991. https://doi.org/10.1080/ 00049158.1990 .10676071

GUIMARÃES-BEELEN, P.M.; BERCHIELLI, T.T.; BUDDINGTON, R.; BEELEN, R. Efeito dos taninos condensados de forrageiras nativas do semi-árido nordestino sobre o crescimento e atividade celulolítica de Ruminococcus flavefaciens FD 1. Arquivo Brasileiro de Medicina Veterinária e Zootecnia, Belo Horizonte, v.58, p.910-917, 2006. http://dx.doi.org/10.1590/SO102-09352006000500029

HASLAM, E. Natural polyphenols (vegetable tannins) as drugs: possible modes of action. Journal of Natural Products, Washington, v.59, p.205-215, 1996. http://dx.doi.org/10.1021/np960040+

HEYMAN, H.M.; HUSSEIN, A.A.; MEYER, J.J.M.; LALL, N. Antibacterial activity of South African medicinal plants against methicillin resistant Staphylococcus aureus. Pharmaceutical Biology, Oxfordshire, v.47, p.67-71, 2009. https://doi. org/10.1080/13880200802434096

HIGINO, S.S.S.; PEREIRA, A.V.; AZEVEDO, T.K.B.; SANTANA, G.M.; FREITAS, A.F.R.; TREVISAN, L.F.A.; AZEVEDO, S.S.; PEREIRA, M.S.V. Avaliação da atividade antimicrobiana de taninos isolados da jurema vermelha (Mimosa arenosa (WilldPoir) sobre Staphylococcus aureus de origem bovina. Agropecuária Técnica, Aréia, v.36, p. 1 15-120, 2015. https://doi.org/10.25066/agrotec.v36i1.23013

JONES, G.A.; MCALLISTER, T.A.; MUIR, A.D.; CHENG, K.J. Effect of sainfoin (Onobrychis viciifolia Scop.) condensed tannins on growth and proteolysis by four strains of ruminal bacteria. Applied and Environmental Microbiology, Washington, v.60, p.1374-1378, 1996.

JORGENSEN, J.H.; TURNIDGE, J.D.; WASHINGTON, J.A. Antimicrobial susceptibility tests: dilution and disk diffusion methods. In: Murray, R.P. et al. Manual of Clinical Microbiology. American Society for Microbiology, Michigan, 7 ed. Washington DC, p.1526-1543, 1999.

LOGUERCIO, A.P.; BATTISTIN, A.; VARGAS, A.C.; HENZEL, A.; WITT, N.M. Atividade antibacteriana de extrato hidro-alcoólico de folhas de jambolão (Syzygiumcumini (L.) Skells). Ciência Rural, Santa Maria, v.35, 2005. http://dx.doi.org/10.1590/ S0103-84782005000200019

MAIA, R.R.; PEREIRA, M.S.V.; ALBUQUERQUE, A.C.L.; PEREIRA, L.F.; MACEDO COSTA, M.R.M. Estudo do efeito antimicrobiano do extrato da goiabeira (psidiumguajava linn) sobre Staphylococcus aureus multirresistentes. Agropecuária Científica no Semi-Árido, Areia, v.5, p.36-40, 2009. http://dx.doi.org/10.30969/ acsa.v5i 1.47

MANSOURI, S. Inhibition of Staphylococcus aureus Mediated by Extracts from Iranian Plants. Pharmaceutical Biology, Oxfordshire, v.37, p.375-377, 1999. https://doi.org/10.1076/ phbi.37.5.375.6058
MASURANI, A.; TAVARES, L.C. Estudos de QSAR-3D em derivados 5-nitro-2-tiofilidênicos com atividade frente a Staphylococcus aureus multi-resistente. Revista Brasileira de Ciências Farmacêuticas, São Paulo, v.43, 2007.

MENEZES, K.M.; PEREIRA, J.V.; MEDEIROS, D.R.; FREITAS, A.F.R.; PEREIRA, M.S.V.; PEREIRA, A.V. Antimicrobial and Anti-Adherent in vitro Activity of Tannins Isolated from Anacardium occidentale Linn.(Cashew) on Dental Biol film Bacteria. Pesquisa Brasileira em Odontopediatria e Clínica Integrada, Campina Grande, v.14, p.191-198, 2014. http://dx.doi.org/10.4034/ PBOCl.2014.143.03

MIN, B.R.; PINCHAK, W.E.; MERKEL, R.; WALKER, S.; TOMITA, G.; ANDERSON, R.C. Comparative antimicrobial activity of tannin extracts from perennial plants on mastitis pathogens. Scientific Research and Essays, Nigeria, v.3, p.66-73, 2008.

MONROE, S.; POLK, R. Antimicrobial use and bacterial resistance. Current Opinion in Microbiology, North Carolina, v.3, p.496-501, 2000.

MUSUMECI, R.; SPECIALE, A.; COSTANZO, R.; ANNINO, A.; RAGUSA, S.; RAPISARDA, A.; PAPPALARDO, M.S.; IAUK, L. Berberis aetnensis $\mathrm{C}$. Presl. extracts: antimicrobial properties and interaction with ciprofloxacin. Journal Antimicrobial Agents, Marseille, v.22, p.48-53, 2003.

PAES, J.B.; DINIZ, C.E.F.; MARINHO, I.V.; LIMA, C.R. Avaliação do potencial tanífero de seis espécies florestais de ocorrência no semi-árido brasileiro. Revista Cerne, Lavras, v.12, p.232-238, 2006.

PEREIRA, A.V.; AZEVEDO, T.K.B.; SANTANA, G.M.; TREVISAN, L.F.A.; HIGINO, S.S.S.; MACÊDO COSTA, M.R.; PEREIRA, M.S.V.; AZEVEDO, S.S. Análise da atividade antimicrobiana de taninos totais de plantas aromáticas do Nordeste brasileiro. Agropecuária Técnica, Areia, v.36, p.109-114, 2015. https://doi.org/10.25066/ agrotec.v36i 1.23009

POL, M.; RUEGG, P.L. Relationship between antimicrobial drug usage and antimicrobial susceptibility of Gram-positive mastitis pathogens. Journal of Dairy Science, Champaign, v.90, p.262-273, 2007.

PRESCOTT, J.F.; HANNA, W.J.; REID-SMITH, R.; DROST, K. Antimicrobial drug use and resistance in dogs. Canadian Veterinary Journal, Ontario, v.43, p.107-16, 2002.

RANG, H.P.; DALE, M.M.. RITTER, J.M.; FLOWER, R.J.; HENDERSON, G. Farmacologia. 7. ed. Rio de Janeiro: Elsevier, 2012.

RODRIGUES, C.G.; FERREIRA, P.R.B.; OLIVEIRA, M.; REIS JÚNIOR, R.; VALÉRIO, H.M.; BRANDI, V.I.; OLIVEIRA, D.A. Antibacterial activity of tannins from Psidium guineense Sw. (Myrtaceae). Journal of Medicinal Plant Research, Nigeria, v.8, p.1095-100, 2014. https://doi.org/10.5897/ JMPR20 14.5500

RODRIGUES, F.A.; BERTOLDI, A.D. The profile of antimicrobial utilization in a private hospital. Ciência \& Saúde Coletiva, Manguinhos, v.15, p.1239-1247, 2010. http://dx.doi. org/10.1590/S1413-81232010000700033 
SAEKI, E.K.; PEIXOTO, E.C.T.M.; MARCUSSO, L.S.M.P.F.; MONTEIRO, R.M. Bovine mastitis caused by Staphylococcus aureus: susceptibility to antimicrobial drugs and the alcoholic extract of própolis. Acta Veterinaria Brasilica, Mossoró, v.5, p.284-290, 2011 . http://dx.doi.org/10.21708/ avb.2011.5.3.2172

SCALBERT, A. Antimicrobial properties of tannins. Phytochemistry, Washington, v.30, p.3875-3883, 1991. http://dx.doi. org/10.1016/0031-9422(91)83426-L

SPINOSA, H.S. Antibioticos que interferem na síntese da parede celular: Betalactâmicos. In: SPINOSA, H.S.; GORNAIK, S.L.; BERNARDI, M.M. Farmacologia Aplicada a Medicina Veterinária. Rio de Janeiro: Guanabara Koogan, 2011.
SULEIMAN, A.; ZARIA, L.T.; GREMA, H.A.; AHMADU, P. Antimicrobial resistant coagulase positive Staphylococcus aureusf romchickens in Maiduguri, Nigeria. Sokoto Journal of Veterinary Sciences, Sokoto-Nigeria, v.11, p.51-55, 2013. http://dx.doi.org/10.4314/sokjvs.v1 1i1.8

WHITE, S.W. Systemic treatment of bacterial skin infectious of dogs and cats. Veterinary Dermatology, Spain, v.7, p.133-143, 1996. https://doi.org/10.1111/j.1365-3164.1996.tb00238.x

YOUN, J.H.; YOON, J.W.; KOO, H.C.; LIM, S.K.; PARK, Y.H. Prevalence and antimicrogram of Staphylococcus intermedius group isolates from veterinary staff, companion animals, and the environment in veterinary hospitals in Korea. Journal of Veterinary Diagnostic Investigation, London, v.23, n.2, p.268-274, 2011 . https://doi. org/10.3382/ps.2013-03175 